\title{
The Effects of Abolishing Corporal Punishment on Learner Behaviour in South African High Schools
}

\author{
Noorullah Shaikhnag \\ Thomas Edwin Buabeng Assan \\ Faculty of Education - North-West University - Mafikeng Campus \\ Noorullah.Shaikhnag@nwu.ac.za, thomas.assan@nwu.ac.za
}

\section{Doi:10.5901/mjss.2014.v5n7p435}

\begin{abstract}
Corporal punishment is a form of disciplinary measure that uses physical force with the intention of causing a learner to experience pain but not injury for reasons of correcting his or her behaviour. Section 10 of the South African Schools Act (84 of 1996), however, prohibits all forms of corporal punishment in schools (RSA, 1996). Despite this ban, many schools continue to practise it widely. Media reports suggest that students in many schools, especially rural schools, display arrogance, violence, rudeness, truancy and other types of misconduct. In the light of above and with the implications of the implementation of the Schools Act in mind, it was investigated whether the South African Government's decision to abolish physical punishment was viable and whether it had any impact on student conduct. A sample was drawn of 400 learners and 100 teachers from 10 high schools in an educational region of the North West Province of South Africa. In contrast to the thrust of the theoretical investigation that revealed that the abolition of corporal punishment would probably lead to an increase in poor behaviour, the empirical investigation, particularly the application of the chi-squared test, indicated no positive relationship between the abolition of corporal punishment and increase in misconduct. The study recommends that alternative forms of disciplinary measures are necessary to minimise misdemeanours among learners.
\end{abstract}

Keywords: Punishment; Corporal punishment; Disruptive behaviour (Learner misconduct); Discipline; Abolition

\section{Introduction and Background}

The present situation in South African schools seems to suggest that a lack of discipline and self-discipline among high school students has led to a continuation of unsuccessful learning and teaching. Discipline in a positive sense refers to learning, regulated scholarship, guidance and orderliness. Discipline may therefore qualify as an integral part of an effective educational endeavour in which parents and teachers give assistance to a learner seeking help (Mabeba \& Prinsloo, 2003, p 34). Some psycho-educationists stress that the main reasons why learners misbehave can be summed up as attention seeking, desire for power (influence, intimidation), revenge (retaliation, vendetta) and a display of inadequacy, frustration or pain (Rogers, 2004, p. 22)

Research indicates that the majority of education students believed that the abolition of corporal punishment had been a mistake leading to poor discipline in schools. Principals in the North West Province of South Africa also pointed out that bullying, assault and fighting among learners were the most common types of misconduct in schools. Absence from class, including arriving late and bunking, is also mentioned as having a major impact on schools. Theft, swearing at teachers, vandalism, intimidation, undermining teacher authority and physical abuse were high on the list (Ferreira, Badenhorst \& Wilkenson, 2007, p 68). The effect of learner misconduct on teaching commitments also seems to suggest that learners who deliberately interrupt educators' teaching through disruptive behaviour was the single most prominent type of misconduct mentioned by a number of headmasters (Rossouw, 2007, p. 220).

\section{Literature Review}

\subsection{Conceptual-theoretical Framework}

Punishment is the act of causing pain, suffering or loss that serves as retribution and where unpleasant consequences follow socially unacceptable behaviour (Webster, 2006:936). Punishment at schools includes expulsion, suspension and physical pain. In view of this, classroom teachers are more likely to show their disapproval by means of facial gestures, reprimands, giving detention, assigning unpleasant activities, ordering time out and sometimes using physical punishment 
(Baron, 2006, p. 24). Moreover, this type of punishment can also be seen as a disciplinary measure that uses physical force with the intention of causing pain to the recipient but not bodily harm. With this in mind corporal punishment may at times be seen as cruel sending the wrong signal to students. Consequently, its application indicates to learners that it is appropriate for teachers to strike learners. Corporal punishment thus creates an atmosphere conducive to violence (Arcus, 2004, p. 148).

Disruptive behaviour is simply behaviour which is not acceptable and is attributable to disciplinary problems in class, in other words it affects the basic rights of the learners to feel safe and be treated with respect (Marais \& Meier, 2010, p. 1). For purposes of this study, conduct, misconduct, behaviour, misdemeanours have been used interchangeably with disruptive behaviour. In order to minimise learner misconduct, discipline which relates to issues of school management, ways of getting things done at schools or education orderliness will have to be strictly implemented. It is further argued that discipline may also be perceived as the development of the individual and the promotion of selfactualisation and empowerment. Discipline thus is important for the safety of all learners (Masitsa, 2008, p. 243). The introduction of the Schools Act 84 of 1996 did not help the discipline process much as corporal punishment was done away with. Abolition is the act of doing away with totally. In essence it is to annul or destroy completely. It is the act of making a practice non-existent, wholly ineffective or inactive (Webster, 2006. P. 3).

Corporal punishment is rather controversial with some psychologists arguing in its favour and others calling for its abolition. In the modern world, however, corporal punishment remains a common way of disciplining children. Many studies have been undertaken on the effectiveness of corporal punishment and it seems that the majority of researchers accept the results of corporal punishment as unpredictable. Even if it discourages misbehaviour, it does not foster appropriate behaviour. It is also argued that corporal punishment negatively affects relationships and often creates resentment and hostility, which have been associated with school dropout and vandalism (Mwamawenda, 2008, p. 289).

\subsection{Corporal Punishment in the South African Context}

In South Africa, corporal punishment has been outlawed. Section 10 of the Schools Act of 1996 has made the administration of corporal punishment a criminal offence in South African schools. Corporal punishment has been used as a quick-fix solution which raises fear and pain and should therefore be replaced by instilling self-discipline. In terms of punishment in educational settings, approaches differ throughout the world. While corporal punishment has almost completely been abandoned in Europe, North America and most African countries, including South Africa, some countries still retain the widespread use of corporal punishment; these include Botswana, Malaysia and Singapore (Temple.ed : 2006). Many South African educators have difficulty finding an alternative to this traditional method of punishment and it is argued that corporal punishment persists because parents use it at home and support its use at school (Msomi, 2004, p.44, Morrel, 2003, p. 292). Corporal punishment belongs to the traditional school room where it was the only form of punishment. It also passed down the ages in the history of schooling until it was challenged by educational theorists of the progressive era (Maphumulo \& Vakalisa, 2008, p. 373).

According to the new South African Schools Act (RSA, 1996), an environment conducive to a healthy study atmosphere may be administered while expulsion and suspension should be exercised with great caution. Learners may be expelled only if they are guilty of serious misconduct after a fair hearing, and suspension should only be seen as a correctional measure not lasting more than five days. Those who advocate corporal punishment argue that the evergrowing disregard for authority among the youth stems from the abolition of physical punishment both at home and at school. This is tantamount to the teacher losing a grip on the learner. Hence the inference, that if used properly, corporal punishment can be an appropriate measure of discipline for serious offences. However, this measure needs to be monitored consistently to ensure its correct usage (Masitsa, 2008, p. 241). Moreover, such punishment often leads to short-term compliance and therefore appears to be effective, but actually has negative short-term and long-term effects (Ancer, 2011, p.10). Studies have established a strong relationship between corporal punishment and the development of aggressive behaviour by learners. Corporal punishment has a tendency to develop aggressive hostility instead of selfdiscipline. For many learners, especially boys, it leads to feelings of revenge, anti-social aggressiveness and a high rate of vandalism (Gregan-Kaylor, 2006, p.160).

Teachers establish classroom leadership in a number of ways. Their styles can be characterised as autocratic, permissive or democratic, whichever reflects the teachers' views of child behaviour and classroom management approaches. Autocratic teachers have a low opinion of human nature and believe that students cannot, or will not, control their own behaviour. Such teachers use their authority to control students by determining and enforcing standards of behaviour in the classroom. On the other hand, permissive disciplinarians have an optimistic view of human nature and maintain that learners, if left alone, will make good decisions and behave favourably. These permissive educators, whose 
main aim is to be liked, very often abdicate their authority to their learners and offer very little guidance (Zabel \& Zabel, 2006, p.124). In comparison, democratic leaders attempt to balance teacher-directed and student-centred activities. Such educators believe that in some situations they need to assume a more directive approach to determining content and activities, while in other situations, learners must assume an active role in deciding the content and nature of activities. This form of discipline usually displays characteristics of leadership, friendliness, inviting nature, stimulation, creative ideas and shared responsibility (Hertley, Ramsey \& Algozzine, 2004, p.66).

The present situation in South African schools demonstrates that a lack of discipline and self-discipline among high school learners has led to a continuation of unsuccessful learning and teaching. As it is unethical to physically punish learners according to the Schools Act, no 10, the permissive style of discipline might be best suited to the circumstances in South Africa. Some form of discipline is essential if meaningful learning is to take place. Guidance and leadership therefore is necessary if learners are to put workable rules and consequences into proper perspective. (De Klerk \& Rens, 2005, p.127) An empirical investigation was conducted based on the theoretical insights that flowed from the conceptualtheoretical framework set out above. The next section reports on the findings of that investigation.

\section{Problem Statement}

School discipline and punishment have been a bone of contention in the education profession for a long time now, yet it would seem there is no end to this issue. Debate founded on religious, social and cultural values suggests that it is essential to punish children, physically, because it helps to bring about the values of society, good conduct and discipline in them (Masitsa, 2008, p. 155). Abolition of corporal punishment is tantamount to loosening the teachers' grip on the learners. The inference here is that, if used judiciously, this type punishment could be an effective way of preventing and curbing misconduct (Ezekiel, 2003, p.1).

It can be argued, on the other hand, that corporal punishment does not result in long-term behavioural change; it rather teaches the child to avoid the punishable behaviour when the person who does the caning is at hand. It is suggested that violent punishment only temporarily stops the learner's behaviour to prevent further beating, only to bottle up resentment and rage which resurfaces at a later stage (Andero \& Stewart, 2004, p.94, Dlamini, 2005, p.1).

From the time students became aware that corporal punishment had been outlawed, a state of unruliness prevailed in a large number of South African schools. Many learners seem to take advantage of teachers since they know that punishment will not be meted out on them physically (Makapela, 2006, p. 1). With this in mind, this article purports to shed light on and provide insight into the problems experienced by schools around three regions in the Area Offices of the North West Province concerning learner conduct as well as into the effects of abolishing corporal punishment on the learning/teaching environment. The study, the findings on which this article reports, concentrated on discovering evidence concerning the effects of abolishing corporal punishment on learner conduct.

As a report on the research that was undertaken, the rest of this article is structured as follows: After a brief outline of the general research method followed, the conceptual and theoretical framework of the study will be outlined. This will be followed by an exposition of research methods pertinent to the empirical part of the investigation. This will be followed by listing the findings, and presenting a discussion in view of the conceptual-theoretical framework. The article concludes with a number of recommendations.

\section{Research Design and Methodology}

\subsection{Introduction}

The research was contextualised by the post-positivist paradigm based on the following assumptions (Creswell, 2008, $\mathrm{p}$. 7): Firstly, all knowledge is conjectural; therefore absolute truth cannot be established. Secondly, research is a process of making claims, thereafter refining them or abandoning them to accommodate other claims that deserve more attention. Finally, post- positivism is not a form of relativism and can therefore retain the idea of objective truth. This is essential for competent enquiry (Creswell, 2008, p.7). The following conceptual-theoretical framework was constructed in the context of these assumptions. The framework is the product of the researchers' constructive-hermeneutic understanding of views expressed in the relevant literature. Conducting research in this manner requires the researcher to be mindful that knowledge is conjectural; hence absolute truth can never be established. This means that evidence found in research is always imperfect and fallible, thus research is a process of making claims which deserves more credit (Philips \& Barbules 2002, p. 123). The design and method followed for the empirical investigation are described in a separate section below.

4.2 Research Design 
The investigation was of a quantitative nature and, as a data collecting technique; it was underpinned by a postpositivistic research theory whose assumptions represent the traditional form of research. These hold true more for quantitative research than the qualitative approach (Creswell, 2009, p. 6). Empirical observation and measurement were utilised to determine the effects of the abolition of corporal punishment on learner behaviour. In order to discover such effects, the null hypothesis tested was that "there is no significant relationship between the abolition of corporal punishment and increase in misdemeanours". Thus it became clear that using the quantitative method in analysing data would be the most appropriate for the study.

\subsection{Research Strategy}

Survey data were used to describe and explain the status of phenomena, to trace change and to draw comparisons. Thus implicit in the notion of survey is the idea that research should have a wide range - a breath-taking view, i.e. a panoramic view and 'taking it all in'. Similar to this research, surveys relate to the present state of affairs and involve an attempt to provide a view of how things are at a specific time at which data is collected (Maree, 2010, p.155, Leedy \& Ormrod, 2005, p.180).

\subsection{Instrumentation}

It was surmised that the best way of gathering information directly from respondents would be by means of a scheduled structured questionnaire. This method is based on a set of questions with fixed wording and indicators of how to answer each question. In this study, a structured (closed-ended) questionnaire using the four (4)-point Likert scale was used since it is characterised by choices between alternative responses that are given (Strongly agree, Agree, Disagree and Strongly disagree). A self-constructed questionnaire with twelve items was used. The questionnaire had only one section and the wording was such that it could easily elicit appropriate reactions from the respondents. With this type of a questionnaire, data can be enlarged and classified more easily and the number of possible responses are limited (Bless \& Higson Smith, 2005, p.108, Wilson, 2009, p.122). 1

1 Copy of the questionnaire is available from the authors

\subsection{Population and Sampling}

The target population included high schools in one educational region of the North West Province $(n=20)$ and it was selected with the assistance of the Area Project Officers regional managers. The findings of the study are therefore valid for schools in this region only.

Simple random sampling was used and the sample size included ten schools ( $n=10)$. In total, 400 questionnaires were distributed to 400 students and 100 were handed out to teachers. The response rate was about $95 \%$.

Table 1: Population and Sample

\begin{tabular}{|c|c|c|c|}
\hline \multicolumn{4}{|c|}{ Population } \\
\hline $\begin{array}{c}\text { Schools in one } \\
\text { region of NW }\end{array}$ & $\begin{array}{c}\text { Number of } \\
\text { schools }\end{array}$ & Learners & Educators \\
\hline & 20 & 1200 & 300 \\
\hline
\end{tabular}

\begin{tabular}{|c|c|c|}
\hline \multicolumn{3}{|c|}{ Sample } \\
\hline $\begin{array}{c}\text { Number of schools } \\
\text { selected }\end{array}$ & Learners & Educators \\
\hline 10 & 400 & 100 \\
\hline
\end{tabular}

\subsection{Ethical considerations}

Ethical guidelines were followed, which included guaranteeing confidentiality and anonymity of the participants. Permission to carry out this investigation was granted by the Provincial Department of Education and further consent was given by the principals to conduct research at their schools.

\subsection{Trustworthiness issues}

To observe reliability and content validity, the questionnaire was structured in such a manner that questions were clearly articulated and directed. Face validity (where all the items had an indication to relate in some way to corporal 
punishment) and content validity (where all items used had a bearing on learner conduct and corporal punishment as described in the theoretical study) were applied. To establish the reliability of the instrument, Cronbach's alpha coefficient was calculated for the questionnaire dealing with misconduct and misdemeanours and the result was 0.801 and this suggests that it was satisfactory (refer Table 2 below).

Table 2: Cronbach's Alpha

\begin{tabular}{|c|c|c|c|c|c|}
\hline Variable & $\mathrm{N}$ & Mean & STD Dev & Cronbach's & Comment \\
\hline School 10 & 200 & 3.75 & 1.27 & 0.801 & Good \& consistent \\
\hline
\end{tabular}

\subsection{Data collection and administration}

The researchers distributed the questionnaires personally. This had the advantage that the purpose of the study could be explained clearly before the respondents attempted to respond to the questions. Most of the completed questionnaires were collected almost immediately, but some had to be collected at a later stage due to students writing tests.

\subsection{Data processing}

The quantitative method was applied in analysing data. The raw data were organised and analysed, and the chi-squared test was applied to test the null hypothesis. With the assistance of statistical consultants, computer-aided statistical analysis was employed in the form of calculations of frequencies, percentages, means and chi-squares by means of meta-analysis (Kaplan, 2005:22).

\section{Findings}

\subsection{Abolishing of Corporal punishment and effect on misdemeanours}

Table 3 below presents the responses to the questionnaire relating to misconduct and misbehaviour. The respondents were requested to respond to twelve statements in connection with misconduct. They were asked to rate each item on a scale of 1 to 4 ( 1 =Strongly Agree, 2=Agree, 3=Disagree, 4=Strongly Disagree)

Table 3: Candidate responses to questionnaire on misdemeanours

\begin{tabular}{|c|c|c|c|c|c|}
\hline \multirow[t]{2}{*}{ Statements } & $\begin{array}{c}\text { Strongly } \\
\text { Agree }\end{array}$ & Agree & Disagree & $\begin{array}{l}\text { Strongly } \\
\text { Disagree }\end{array}$ & Total \\
\hline & 1 & 2 & 3 & 4 & \\
\hline $\begin{array}{l}\text { Since the banning of physical punishment: Learners } \\
\text { are not prepared to write tests on a regular basis }\end{array}$ & $121(24.6 \%)$ & $\begin{array}{c}236 \\
(48.1 \%)\end{array}$ & $\begin{array}{c}119 \\
(24.2 \%)\end{array}$ & $15(3.1 \%)$ & $\begin{array}{c}491 \\
(100)\end{array}$ \\
\hline Learners have less respect for teachers & $70(14.3 \%)$ & $\begin{array}{c}224 \\
(45.6 \%)\end{array}$ & $137(27.9)$ & $60(12.2 \%)$ & $\begin{array}{c}491 \\
(100)\end{array}$ \\
\hline Students steal more property & $131(26.6 \%)$ & $\begin{array}{c}174 \\
(35.3 \%)\end{array}$ & $\begin{array}{c}96 \\
(19.5 \%)\end{array}$ & $92(18.7 \%)$ & $\begin{array}{c}493 \\
(100)\end{array}$ \\
\hline Learners damage school property frequently & $54(11.0 \%)$ & $\begin{array}{c}159 \\
(32.4 \%)\end{array}$ & $\begin{array}{c}173 \\
(35.2 \%)\end{array}$ & $105(21.4 \%)$ & $\begin{array}{c}491 \\
(100) \\
\end{array}$ \\
\hline Learners fight among themselves regularly & $84(17.1 \%)$ & $\begin{array}{c}216 \\
(44.0)\end{array}$ & $135(27.5)$ & $56(11.4 \%)$ & $\begin{array}{c}491 \\
(100)\end{array}$ \\
\hline Students disobey the Prefects & $102(20.7 \%)$ & $\begin{array}{c}201 \\
(40.9 \%)\end{array}$ & $\begin{array}{c}138 \\
(28.0 \%)\end{array}$ & $51(10.4 \%)$ & $\begin{array}{c}492 \\
(100)\end{array}$ \\
\hline Learners smoke in toilets regularly & $47(9.6 \%)$ & $\begin{array}{c}134 \\
(27.5 \%)\end{array}$ & $\begin{array}{c}221 \\
(45.3 \%)\end{array}$ & $86(17.6 \%)$ & $\begin{array}{c}488 \\
(100)\end{array}$ \\
\hline Learners drink alcohol at school frequently & $148(30 \%)$ & $\begin{array}{c}190 \\
(38.5 \%)\end{array}$ & $\begin{array}{c}86 \\
(17.4 \%)\end{array}$ & $69(14.0 \%)$ & $\begin{array}{c}493 \\
(100)\end{array}$ \\
\hline Students stay away from school often (truancy) & $34(6.9 \%)$ & $\begin{array}{c}127 \\
(25.9 \%)\end{array}$ & $\begin{array}{c}161 \\
(32.8 \%)\end{array}$ & $169(34.4 \%)$ & $\begin{array}{c}491 \\
(100)\end{array}$ \\
\hline Students do drugs often & $78(16.0 \%)$ & $\begin{array}{c}228 \\
(46.6 \%)\end{array}$ & $\begin{array}{c}81 \\
(16.6 \%)\end{array}$ & $102(20.9 \%)$ & $\begin{array}{c}489 \\
(100)\end{array}$ \\
\hline Students are involved in sexual abuses more often & $44(9.0 \%)$ & 186 & 144 & $115(23.5 \%)$ & 489 \\
\hline
\end{tabular}




\begin{tabular}{|c|c|c|c|c|c|}
\hline & & $(38.0 \%)$ & $(29.4 \%)$ & $(100)$ \\
\hline Learners (females) fall pregnant often & \multirow{2}{*}{$164(33.5 \%)$} & $\begin{array}{c}187 \\
(38.2 \%)\end{array}$ & $\begin{array}{c}98 \\
(20.0 \%)\end{array}$ & $41(8.4 \%)$ & $\begin{array}{c}490 \\
(100)\end{array}$ \\
\hline
\end{tabular}

Figure 1, the bar chart, indicates that the majority of participants agreed that the abolition of corporal punishment does lead to increased misdemeanours

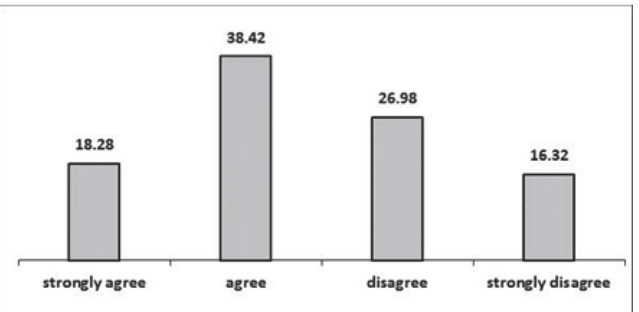

Figure 1: Teacher and learner responses with regard to corporal punishment and its effect on misconduct

The analysis indicates that the majority (73\%) of the respondents are not prepared to write class tests on a regular basis, while $60 \%$ agreed that students have less respect for educators. A large percentage of respondents $70 \%$ asserted that students stole more property since physical punishment was outlawed and only $43 \%$ believed that they damaged school property. The majority of participants $61 \%$ accepted that students fought among themselves since the abolition of physical punishment. A large number of respondents $62 \%$ maintained that learners do not obey the prefects and only $37 \%$ indicated that students smoke in toilets. The majority $68 \%$ noted that more alcoholic drinks were consumed at schools since the banning of corporal punishment, however, only 33\% accepted that learners play truant or stay away from schools on a regular basis. A large number of participants $63 \%$ believed that students do drugs more often since the abolition of physical punishment, while $48 \%$ thought that students commit sexual offences regularly. A large portion of the respondents $71 \%$ suggested that female learners fall pregnant more regularly since the abolition of corporal punishment.

\subsection{Relationship between abolishing of corporal punishment and misdemeanours}

Based on the findings of the study, it is evident that the abolition of corporal punishment played a role in the increase of learner misdemeanours such as drinking, smoking, cheating and truancy at schools. However, the chi-squared test applied to the findings indicates that no significant relationship exists between the abolition of corporal punishment and increased misdemeanours. Consequently there was no need to reject the null hypothesis; this suggests that there was no significant relationship between the abolition of corporal punishment and the increase in misdemeanours such as drinking, smoking, cheating and truancy (see Table 4).

Although the data, taken at face-value, showed that the abolition of physical punishment did have an effect on misconduct, the chi-squared test applied to the data indicated that no significant relationship existed between the abolition of corporal punishment and increased misdemeanours, hence the failure to reject the null hypothesis. As the Pearson chi-square ( $P$ value) values were 0.280 and $0.474>$ than 0.05 (significant point) (Table 4), the null hypothesis could not be rejected. Acceptance of the null hypothesis implied that the abolition of corporal punishment did not play a major role in increased misdemeanours though the literature survey indicates to the contrary.

Table 4: Chi-squared tests

\begin{tabular}{|c|c|c|c|c|c|}
\hline & Value & df & Asymp. Sig. (2-sided) & Exact Sig. (2-sided) & Exact Sig. (1-sided) \\
\hline Pearson Chi-Square & $1.169 \mathrm{a}$ & 1 & .280 & & \\
Continuity Correction & .354 & 1 & .552 & & \\
Likelihood Ratio & 1.197 & 1 & .274 & .367 & .278 \\
Fisher's Exact Test & & & & & \\
Linear-by-Linear Association & 1.104 & 1 & .293 & & \\
N of Valid Cases & 18 & & & & \\
\hline
\end{tabular}

3 cells $(75.0 \%)$ have expected count less than 5 . The minimum expected count is 3.11 . 


b. Computed only for a 2x2 table
Chi-Squared Tests
\begin{tabular}{|l|c|c|c|c|c|}
\hline & Value & df & Asymp. Sig. (2-sided) & Exact Sig. (2-sided) & Exact Sig. (1-sided) \\
\hline Pearson Chi-Square & $.513^{\mathrm{a}}$ & 1 & .474 & & \\
Continuity Correction & .049 & 1 & .826 & & \\
Likelihood Ratio & .523 & 1 & .470 & .637 & .417 \\
Fisher's Exact Test & & & & & \\
Linear-by-Linear Association & .485 & 1 & .486 & & \\
N of Valid Cases & 18 & & & & \\
\hline
\end{tabular}

a. 3 cells (75.0\%) have expected count less than 5. The minimum expected count is 2.72 .

\section{Discussion}

Generally speaking, theory, as expounded above in the conceptual-theoretical framework, seems to suggest that learner misdemeanours might have escalated since the abolition of corporal punishment in schools. This was corroborated by Masitsa's study (2008, p. 259) in which it was found that learners were not sufficiently disciplined; among others, they were guilty of stealing other learners' property, vandalizing school property, fighting amongst themselves and also stealing school property. All this constitutes serious misdemeanours, and according to the Department of Education guidelines on school discipline, disciplinary measures for such misconduct should be applied.

The empirical data in the study reported here were cross tabulated, and no significant relationship was found between the abolition of corporal punishment in schools and the increase in misdemeanours such as drinking, smoking, cheating and truancy. Whereas the theoretical analysis of this study seems to suggest an escalation in misdemeanours in the absence of corporal punishment, the chi-squared test applied to the findings suggests no significant relationship between abolition of physical punishment and bad behaviour. One reason for this contradiction could be the presence of a possible (and unforeseen) bias inherent in the sample. This bias may have been present despite all efforts to draw a fully representative sample.

Oosthuizen (2007) conducted a study on methods for dealing with misdemeanours in the Kenneth Kaunda region of the North West Province of South Africa, and found that teachers in that region regarded corporal punishment as the most ineffective method of dealing with learner misconduct. Interviews conducted with various respondents who participated in this study, showed that the reason for this view can be attributed to teachers' apprehension in view of the abolishment of corporal punishment by Section 10 of the South African Schools Act of 1996 in terms of which the infliction of bodily punishment became a criminal offence. Put differently, the discrepancy between the theoretical and empirical findings of this study can probably be ascribed to the respondents' prejudice against, even rejection of corporal punishment since they were aware of the fact that the infliction of such punishment would be an offence according to South African law.

\section{Recommendations}

In the light of the findings and empirical evidence, it is suggested that teachers consider alternate ways of bringing about discipline. Providing alternative techniques to teachers can contribute to better understanding of the learners. The use of such techniques brought about positive results as shown by the research results of Lessing and Dreyer (2007, p.128). The state should furthermore take responsibility to communicate the regulations for the use of corporal punishment should it be decided to reintroduce it. Non-governmental institutions should also give some advice in this regard.

\section{Conclusions}

The chi-squared test applied to the analysed data confirmed that no real connection existed between the abolition of corporal punishment and increase in student misconduct (Table4) The study showed that teachers and principals were not too keen on using corporal punishment as a means of restoring good behaviour. This is understandable in view of the fact that international studies have linked corporal punishment to increases in aggression, more disruptive behaviour in classrooms, vandalism, lower academic achievement, poor attention span, school phobia, depression and even retaliation against teachers (Ancer, 2011, p.9) and also in view of the abolishment of corporal punishment by South African legislation. In view of this, it is suggested that educators and the Department of Education apply their minds to the 
problem of replacing corporal punishment with disciplinary measures that will be pedagogically justifiable such as giving learners good advice and asking parents to curtail their allowance and perks.

\section{References}

Ancer, J. (2011). Corporal punishments' effects linger forever. Sunday Times 9 June 2011.

Andero, A.A. and Stewart, A (2004). Issues of corporal punishment: re-examined. Journal of Instructional Psychology, 29(2):90-96

Arcus, D. (2004). School shooting fatalities and school corporal punishment: A look at the States. Aggressive behaviour. Indianapolis: Wiley Publishers.

Baron, J.H. (2006). Corporal Punishment of children in England and the United States: Current issues. The Mount Sinai Journal of Medicine, 72(1) 45-46

Bless, C. \& Higson Smith,T. (2005). Fundamentals of Social Research Methods; An African perspective. Cape Town; Inta \& Co.

Creswell, J.W. (2008) Qualitative inquiry and research design: Choosing among five traditions, (2nd Ed) Thousand Oaks: Sage.

Creswell, J.W. (2009) Research Design, Qualitative, Quantitative and Mixed methods approach. London : Sage.

De Klerk, I \& Rens, J. (2005). The role of values in school discipline. Koers, 68(4):353-371.

Dlamini, Z. (2005). Spare the rod and groom the child. Experts say that the scolding, spanking and other forms of punishment can do more harm than good. City Press, 12 June.

Ezekiel, J. (2003). Opponents underrate corporal punishment in schools. Business Times, 16 January.

Ferreira, A. Badenhorst, G. \& Wilkenson, A. (2007). Teacher values and the use of punishment in managing learner behaviour: An Interpretive Perspective. Perspectives on learner conduct. Potchefstroom: Platinum Press.

Gregan-Kaylor, A. (2006). The effect of corporal punishment on anti- social behaviour in children. National Association of Social workers, 28 (3): $153-162$

Hertley, D, Ramsey, A. \& Algozinne, B. (2004). Management leadership and the emotional order of the school. Journal of Educational Psychology, 195(5); 583-594

Kaplan, D. (2005). The Sage handbook on qualitative methodology for the social sciences. London : Sage Publication.

Leedy, P.D. \& Ormrod, J.E. (2005). Practical Research. Upper Saddle River: Pearson

Lessing, A.C. \& Dreyer, J. 2007. Every teachers dream: discipline is no longer a problem in South African Schools. Pretoria: Van SchaikPublishers.

Mabeba, M.Z. \& Prinsloo, E. (2003). Perceptions of discipline and encouraging discipline problems in secondary education. South African Journal of Education, 20(1);34-41

Makapela, L. (2006). Learners claim cane still used. Daily Dispatch, 10 May.

Maphumulo, N.C. \& Vakalisa, N.C.G. (2008). Classroom Management. In Jacobs, M. Vakalisa, N. \& Gawe, N. Eds. Teaching-learning dynamics - a participating approach. Johannesburg: Heinsmann. P339

Marais, P \& Mayer, C. (2010). Disruptive behaviour in the Foundation Phase Schooling. South African Journal of Education, 30(1)

Maree, K. (2010). First Steps in Research. Pretoria : Van Schaik Publishers.

Masitsa, G. (2008). Discipline and disciplinary measures in the Free State township schools: Unresolved problems. Acta Academica 40(3) 234-270

Morrel, R. (2003). Corporal Punishment in South African Schools: A neglected explanation for its persistence. South African Journal of Education 21(4): $292-299$

Msomi, S. (2004). KZN School continues use of cane. www.corpun.com Accessed 05.05.2005

Mwamwenda, T. (2008). Educational Psychology: An African Perspective. Umtata: Butterworths.

Oosthuizen, I.J. (2007). Report on learner discipline in the Southern Region of North West. Potchefstroom: Faculty of Educational Sciences.

Philips, D.C. \& Barbules, N.C. (2002). Positivism and Educational Research. Lanham:Rowman \&Littlefields Publishers.

Rogers, B. (2004) The Language of Discipline: A practical approach to classroom management ( $\left.6^{\text {th }} \mathrm{Ed}\right)$ Plymouth: Northcode House. $163 p$

Republic of South Africa (1996). Schools ACT, no. 84 of 1996. Pretoria: Government Printer.

Rossouw, J.P. (2007). The effect of learner discipline on educator security- An informal qualitative inquiry. Oosthuizen et al (eds) 2007: 212-227.

Temple. (2006). Corporal punishment. www.temple.edu-corporal. Accessed July, 2006.

Webster's (2006). Third New International Dictionary. Vol 11, New York: G and C Merriam Co.

Wilson, E. (2009). School based research: A guide for education students. London: Sage.

Zabel, R.H \& Zabel, M.K. (2006) Classroom Management in context (6th Ed.) Boston: Houghton Mifflin 395p 